\title{
Performance of solar radiation models for obtaining reference evapotranspiration to Santa Maria-RS, Brazil
}

\author{
Ricardo Boscaini ${ }^{1} \oplus$, Adroaldo Dias Robaina ${ }^{1} \oplus$, Marcia Xavier Peiter ${ }^{1} \oplus$, Jhosefe Bruning ${ }^{1} \oplus$, \\ Silvana Antunes Rodrigues ${ }^{1} \oplus$, Juciano Gabriel da Silva ${ }^{1} \oplus$, Elton Pilar Medeiros ${ }^{1} \oplus$, Jessica Dariane Piroli ${ }^{1} \odot$

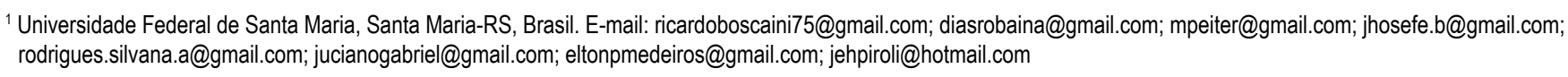

ABSTRACT: In the absence of observed data from Solar radiation (Sr), it is possible to estimate it using mathematical models. In general, the models vary in degree of complexity and the adjustment coefficients, and these must be calibrated to the place of interest to obtain the best performance. In this regard, the present work aims to evaluate the performance of simplified models of solar radiation in obtaining reference evapotranspiration. The data were obtained from the automatic meteorological station of the National Meteorological Institute (Inmet), located in Santa Maria - RS, Brazil. In the estimates of global solar radiation and its influence on reference evapotranspiration, ten models were evaluated, five models with the coefficients calibrated and five models, with the coefficients determined by the authors. It was observed that all the models studied presented performance index above 0.82 , indicating "optimal" performance. Thus, both calibration and non-calibration models to obtain Sr do not interfere with ETo estimation. Therefore, given the impossibility of obtaining $\mathrm{Sr}$ data in meteorological stations, it is possible to use any of the models analyzed.

Key words: air temperature; evaporative demand; Penman-Monteith; water requirement

\section{Desempenho de modelos de radiação solar para obtenção da evapotranspiração de referência para Santa Maria-RS, Brasil}

RESUMO: Na ausência de dados observados de Radiação Solar (Rs) é possível estimá-la mediante a utilização de modelos matemáticos. Em geral, os modelos variam em grau de complexidade e nos coeficientes de ajuste, e esses devem ser calibrados para o local de interesse para obtenção do melhor desempenho. Neste sentido, o presente trabalho tem como finalidade avaliar o desempenho de modelos simplificados de radiação solar na obtenção da evapotranspiração de referência. Os dados foram adquiridos junto a estação meteorológica automática do Instituto Nacional de Meteorologia (Inmet), localizada na cidade de Santa Maria - RS. Nas estimativas de radiação solar global e sua influência na evapotranspiração de referência, foram avaliados dez modelos, sendo cinco modelos com os coeficientes calibrados e cinco modelos, com os coeficientes determinados pelos autores. Observou-se que, todos os modelos estudados, apresentaram índice de desempenho acima de 0,82, indicando "ótimo" desempenho. Dessa forma, tanto os modelos com calibração quanto os sem calibração para a obtenção da Rs, não interferem na estimativa da ETo. Sendo assim, dada a impossibilidade de se obter os dados de Rs nas estações meteorológicas, é possivvel utilizar qualquer um dos modelos analisados.

Palavras-chave: temperatura do ar; demanda evaporativa; Penman-Monteith; necessidade hídrica 


\section{Introduction}

Solar radiation $(\mathrm{Sr})$ is the main input variable in the estimation of the reference evapotranspiration (ETo) to later calculate the irrigation blade (Tabari et al., 2016). The use of this technique is of paramount importance in studies related to the modeling of crop growth, plant production and studies on the flow of water in the soil-plant-atmosphere system (Quej et al., 2016; Jamil \& Akhtar, 2017). However, unlike other climatological variables such as air temperature, duration of sunlight and relative air humidity, solar radiation $(\mathrm{Sr})$ measurements are relatively sparse in several places in the world, especially in developing countries (Jahani et al., 2017).

The quantification of solar radiation $(\mathrm{Sr})$ is performed by measuring instruments such as pyranometers, radiometers, and actinographs (Besharat et al., 2013). However, the direct obtaining of the solar radiation data $(\mathrm{Sr})$ is not always available, since few meteorological stations have records of solar radiation, due to the high costs of the instruments, maintenance, and calibration (Fan et al., 2018a).

As an alternative to places where there are no data records of solar radiation, estimated values can be obtained with the use of alternative mathematical models to quantify solar radiation (Mohammadi et al., 2016). These models differ from each other, by the degree of complexity and by input variables (Mostafa et al., 2014). However, it is important to emphasize that the models are generally restricted to the conditions for which they were developed, rendering them inefficient if they are not properly calibrated and tested for the climatic conditions of the new place (Benghanem \& Mellit, 2014). As they are properly calibrated, they have the benefit of using meteorological elements registered at the place of study, thus representing the local meteorological conditions (Carvalho et al., 2011).
In general, models estimating $\mathrm{Sr}$ based on insolation have better results when compared to models based on other meteorological elements, due to the high relationship between insolation and global solar radiation flux density (Mostafa et al., 2014; Hassan et al., 2016; Fan et al., 2018b). However, its application is often limited by the lack of records of insolation in meteorological stations (Hassan et al., 2016). In this context, the estimation models of Sr based on air temperature are more attractive and feasible options (Almorox et al., 2013).

In this context, the present work aims to evaluate the performance of simplified models of solar radiation in obtaining reference evapotranspiration, using the city of Santa Maria - RS as a case study.

\section{Materials and Methods}

To conduct the present study, daily meteorological data obtained from an automatic station of the National Institute of Meteorology (Inmet), located in the dependencies of the Federal University of Santa Maria (Figure 1), were used, which had a historical series of data available. Whose geographical coordinates are: latitude $29 \circ 42^{\prime} 25^{\prime \prime}$, longitude $53 \circ 48^{\prime} 42^{\prime \prime} \mathrm{W}$, and altitude of 95 meters. The climate of the city is characterized, according to Koppen, as being humid subtropical (Cfa), without dry season, with the warmest month average temperature over $22{ }^{\circ} \mathrm{C}$ and an annual average rainfall of $1.616 \mathrm{~mm}$ (Alvares et al., 2013).

Solar radiation $(\mathrm{Sr})$ was estimated by ten simplified models (Table 1), five models with the calibration of their coefficients with the aid of TableCurve 2D v5.01 software (Systat, 2002). The data collection period ranged from 2002 to 2018, where $80 \%$ of the data were used to perform the coefficient calibration and $20 \%$ for validation.

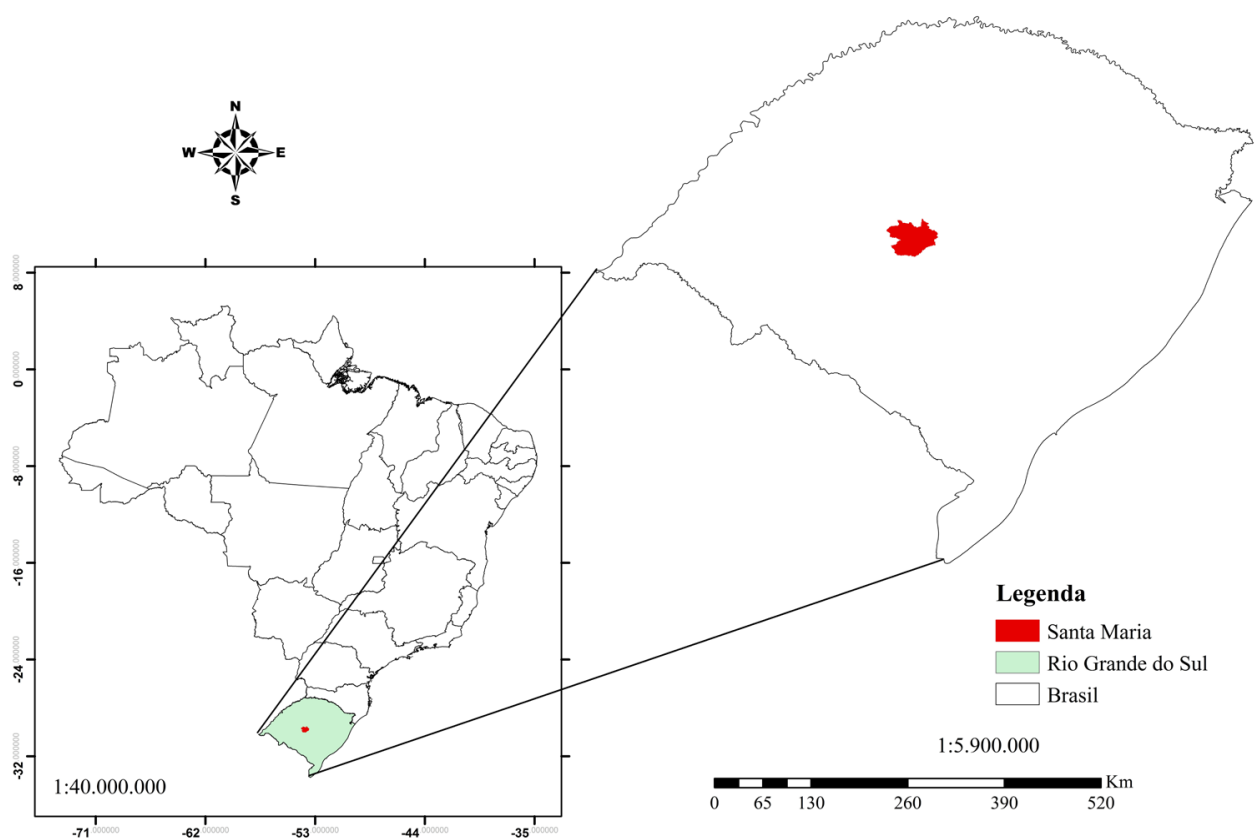

Figure 1. Geographic location of the state of Rio Grande do Sul, highlighting the city of Santa Maria-RS, Brazil. 
Table 1. Global solar radiation estimation models evaluated.

\begin{tabular}{|c|c|c|c|c|}
\hline Eq. & Abbreviation & Equation & Coefficients & Reference \\
\hline 1 & BA & $R_{S}=\left\{a\left[\left(T_{\max }-T_{\min }\right)^{0.5}\right] b\right\}$ & $a, b$ & Ball et al. (2004) \\
\hline 2 & $\mathrm{BC}$ & $\begin{array}{c}R_{S}=a \cdot\left[\exp \left(-b \Delta T^{c}\right)\right] \cdot R_{a} \\
b=0.036 \exp \cdot(-0.154 \cdot \overline{\Delta T})\end{array}$ & c & Bristow \& Campbell (1984) \\
\hline 4 & $\mathrm{Ha}$ & $R_{S}=a \cdot\left(T_{\max }-T_{\min }\right)^{0.5} \cdot R_{a}$ & a & Hargreaves (1981) \\
\hline 5 & MV & $R_{S}=0.75 \cdot\left(1-\exp \left(-b \Delta T^{2}\right)\right) \cdot R_{a}$ & $b$ & Meza \& Varas (2000) \\
\hline 8 & GD & $R_{S}=R_{a} \cdot\left\{0.68\left[1-\exp \left(-0.03\left(T_{\max }-T_{\min }\right)^{2.02}\right)\right]\right\}$ & - & Goodin et al. (1999) \\
\hline 9 & HS & $R_{S}=K_{r s} \cdot \sqrt{\left(T_{\max }-T_{\min }\right)} \cdot R_{a}$ & - & Hargreaves \& Samani (1982) \\
\hline 10 & WS & $R_{S}=0.75 \cdot\left(1-\exp \left(-b \frac{\Delta T^{2}}{R_{a}}\right)\right) \cdot R_{a}$ & - & Weiss et al. (2001) \\
\hline
\end{tabular}

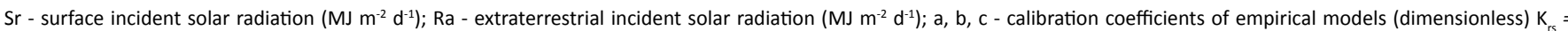
empirical coefficient ( 0.16 for inland cities and 0.19 for coastal cities); $\Delta \mathrm{T}$ - thermal amplitude; $\Delta \mathrm{T}$ - average thermal amplitude; $\mathrm{T}_{\min }-\mathrm{minimum}$ air temperature; $\mathrm{T}_{\max }-\mathrm{maximum}^{\mathrm{rs}}$ temperature.

Thus, the coefficients for each equation were generated and used to estimate solar radiation according to each model. The estimated values were compared with the measured solar radiation values. For the other models, the coefficients proposed by the authors were used. The meteorological variables used in this study were: maximum and minimum temperature, relative air humidity, solar radiation, and wind speed.

Before conducting the $\mathrm{Sr}$ estimates, some data failures were identified in the historical series. Corrections to these failures were filled with the aid of the Clima software developed by the Paraná Agronomic Institute - IAPAR (Faria et al., 2002).

Performance comparisons of solar radiation estimation methods were performed using the Penman-Monteith equation (Equation 11) as a reference. The results of the estimation of the reference evapotranspiration with the data of $\mathrm{Sr}$ measured at the station were considered as standard, and they were compared with the results obtained from the estimate of the reference evapotranspiration using $\mathrm{Sr}$ data estimated by the abovementioned models (Table 1 ).

$$
\mathrm{ET}_{\mathrm{o}}-\mathrm{PM}=\frac{0.408 \Delta\left(\mathrm{R}_{\mathrm{n}}-\mathrm{G}\right)+\gamma\left(\frac{900}{\mathrm{~T}+273}\right) \mathrm{v}\left(\mathrm{e}_{\mathrm{s}}-\mathrm{e}_{\mathrm{a}}\right)}{\Delta+\gamma(1+0.34 \mathrm{v})}
$$

where: $\mathrm{ET}_{0}-\mathrm{PM}$ is the reference evapotranspiration, in lawn, $\mathrm{mm} \mathrm{d}^{-1} ;\left(\mathrm{R}_{\mathrm{n}}\right)$ is the net radiation, MJ. $\mathrm{m}^{-2} \cdot \mathrm{d}^{-1} ;(\mathrm{G})$ is the heat flux in the soil, MJ. $\mathrm{m}^{-2} \cdot \mathrm{d}^{-1} ; \mathrm{T}$ is the average air temperature, ${ }^{\circ} \mathrm{C} ; \mathrm{v}$ is the average wind speed at $2 \mathrm{~m}$ height, $\mathrm{m} \cdot \mathrm{s}^{-1} ;\left(\mathrm{e}_{\mathrm{s}}-\mathrm{e}_{\mathrm{a}}\right)$ is the vapor pressure deficit, $\mathrm{kPa} ; \Delta$ - is the vapor pressure curve, $\mathrm{kPa} .{ }^{\circ} \mathrm{C}^{-1} ; \gamma$ is the psychometric constant, $\mathrm{kPa}{ }^{\circ} \mathrm{C}^{-1}$ and 900 is the conversion factor.

To evaluate the performance of each model and its influence on obtaining ETo, the following statistical indices were used: coefficient of determination $\left(R^{2}\right)$ of linear regressions between measured and estimated values, rootmean-square error (RMSE), absolute error (MBE), index (d) proposed by Willmott (1981), correlation coefficient ( $r$ ) and
Camargo \& Sentelhas index (Id) (1997), adapted by Pimenta et al. (2018), according to (Table 2). For the "RMSE" indicator, the lower its value, the better the model performance. For the "MBE" indicator, positive values overestimate and negative values underestimate the estimated values. On the other hand, the index (Id) qualifies the models according to their performance, being the best those that obtained values close to one, that is, greater linear statistical dependence among the variables (Table 3).

Table 2. Performance indicators, root-mean-square error (RMSE), mean bias error (MBE), Willmot index (d), correlation coefficient ( $r$ ) and Camargo \& Sentelhas index (Id) used to classify the models.

\begin{tabular}{|c|c|c|}
\hline Eq. & $\begin{array}{c}\text { Performance } \\
\text { parameters }\end{array}$ & Equations \\
\hline 12 & RMSE & $\sqrt{\left(N^{-1} \sum_{i=1}^{n}\left(P_{i}-O_{i}\right)^{2}\right)}$ \\
\hline 13 & MBE & $N^{-1} \sum_{i=1}\left|P_{i}-O_{i}\right|$ \\
\hline 14 & D & $1-\left[\frac{\sum_{i=1}^{n}\left(P_{i}-O_{i}\right)^{2}}{\sum_{i=1}^{n}\left(\left|P_{i}-O_{i}\right|+\left|O_{i}-O\right|\right)^{2}}\right]$ \\
\hline \multirow[b]{2}{*}{15} & \multirow[b]{2}{*}{$R$} & $\sum_{i=1}^{n}\left(P_{i}-P\right)\left(O_{i}-O\right)$ \\
\hline & & $\sqrt{\sum_{i=1}^{n}\left(P_{i}-P\right)^{2} \sum_{i=1}^{n}\left(O_{i}-O\right)^{2}}$ \\
\hline 16 & Id & $r . d$ \\
\hline
\end{tabular}

$\mathrm{Pi}$ are the estimated values, $\mathrm{Oi}$ the observed values, $\mathrm{P}$ the average of the estimated values, and $\mathrm{O}$ the average of the observed values; $\mathrm{N}=$ number of observations; $r=$ correlation coefficient.

To verify if, in fact, the ETo values estimated by the models differ significantly between the ETo values measured, the t-test derived from RMSE and MBE (Togrul \& Togrul, 2002) was used, according to Equation 17.

$$
\mathrm{t}=\left[\frac{(\mathrm{n}-1) \mathrm{MBE}^{2}}{\mathrm{RMSE}^{2}-\mathrm{MBE}^{2}}\right]^{0.5}
$$


Table 3. Criteria to classify the performance of global solar radiation estimation models by the index Id.

\begin{tabular}{cc}
\hline Values of Id & Classification \\
\hline $0.90-1.00$ & Excellent \\
$0.80-0.90$ & Optimal \\
$0.70-0.80$ & Very Good \\
$0.60-0.70$ & Good \\
$0.50-0.60$ & Moderately Good \\
$0.40-0.50$ & Moderate \\
$0.30-0.40$ & Moderately Bad \\
$0.20-0.30$ & Poor \\
$0.10-0.20$ & Very Poor \\
$0.00-0.10$ & Terrible \\
\hline
\end{tabular}

Source: Pimenta et al. (2018).

The critical value of $t$ was obtained from the statistical table $\left(t_{\text {tab }} t\right.$-Student), with significance level $(\alpha)$, and $(n-1)$ degrees of freedom. A model was considered statistically significant (accepting the null hypothesis, $\mathrm{Ho}: \mathrm{Pi}=\mathrm{Oi}$ ) in the interval (1 $\alpha)$, if the calculated value of $t$ is less than the critical value. In the present study, the significance level chosen was 0.05 , with $\mathrm{n}=5.844$ and $\mathrm{t}_{\mathrm{tab}}=1.96$.

\section{Results and Discussions}

Based on the ten estimation models of the global solar radiation (Sr) studied, five of them were selected, according to (Table 4), for calibration of the coefficients. For the other models, we used the coefficients determined by the authors themselves (without calibration).

The coefficient " $\mathrm{c}$ " of Bristow \& Campbell (BC) showed little variation for the studied years, with a mean value of 2.02, which could be used, showing that it was not necessary to calibrate this coefficient for Santa Maria - RS and other climatologically similar places.

For the Hargreaves model ( $\mathrm{Ha}$ ), the coefficient "a" obtained a mean value of 0.16 . This value was $6.1 \%$ higher than those obtained by (Liu et al., 2009) and $5.7 \%$ to those obtained by (Almorox, 2011), although close to that recommended by Allen et al. (1998) to an inland location and uncalibrated, emphasizing the universality of this model.

The coefficient " $b$ " obtained for the Meza \& Varas (MV) model was 0.010 , which is the same as those presented by the authors Meza \& Varas (2000), who suggest that the value of " $b$ " after its calibration is in the range of 0.004 to 0.010 .

Table 4. Values of the calibration coefficients of global solar radiation estimation models of Ball et al. (2004) (BA), Bristow \& Campbell (BC) (1984), Chen et al. (2004) (CH), Hargreaves (1981) (Ha) and Meza \& Varas (2000) (MV), for Santa Maria RS, Brazil.

\begin{tabular}{cccc}
\hline \multirow{2}{*}{ Models } & \multicolumn{3}{c}{ Calibrated Coefficients } \\
\cline { 2 - 4 } & $\mathbf{a}$ & $\mathbf{b}$ & $\mathbf{c}$ \\
\hline Ball (BA) & 0.10 & 1.33 & - \\
Bristow \& Campbell (BC) & - & - & 2.02 \\
Chen (CH) & 0.10 & 0.67 & - \\
Hargreaves (Ha) & 0.16 & - & - \\
Meza \& Varas (MV) & - & 0.010 & - \\
\hline
\end{tabular}

The models proposed by Ball (BA) and Chen $(\mathrm{CH})$ presented mean results for the coefficient "a" of 0.10 , values below those found by (Macêdo et al., 2016), in six cities of the state of Ceará, with a mean of 0.33 for the BA model and 0.35 for the $\mathrm{CH}$ model. The same occurred for the coefficient " $b$ ", where the values were below those found by (Macêdo et al., 2016), who found mean values of 0.58 for Ball and 0.28 for Chen.

In Figure 2 we represent the correlations between the reference evapotranspiration values estimated by PenmanMonteith using the solar radiation estimated by the abovementioned models and the values estimated by PenmanMonteith using the data measured at the weather station.

The dispersion of the points around the 1:1 trend line and the straight line presented similar behavior for most models. The Meza \& Varas model (2000) presented the best fit with a coefficient of determination $\left(R^{2}\right)$ of 0.89 .

Although they presented a small trend to overestimate/ underestimate ETo, all the models had coefficients of determination $\left(R^{2}\right)$ ranging from 0.73 to 0.89 . These values are close to those found by Bandyopadhyay et al. (2008) and Conceição (2010) who obtained $R^{2}$ values higher than 0.70 for several locations on different continents. However, lower than the values obtained by Abraha \& Savage (2008), who found $R^{2}$ of 0.95 .

The performance of $\mathrm{Sr}$ estimation models in obtaining ETo can be explained by the fact that this is the main energy source for the evapotranspiration process, being the element that most interferes in this process (Tagliaferre et al., 2015). According to Minuzzi et al. (2018), Sr has a strong influence on this determination. Besides, it affects all other elements, as reported by Pereira et al. 2015). Studies by Lemos Filho et al. (2010) show that the meteorological elements have great spatial variability. Therefore, in the absence of $\mathrm{Sr}$ data, it is better to estimate it by calibrated empirical models than to have simpler models for calculating ETo.

In this study, we also used the t-test, where the ETo estimates for all models studied did not differ, at a 0.05 probability level, in relation to observed values, since all $t$ values are less than $t_{0.05}=1.96$.

(Table 5) shows the values of RMSE, MBE, and $R^{2}$, the results obtained showed a good performance of the models studied, indicating the models of Ball and Chen as the best, followed by Hargreaves, Bristow \& Campbell, and Meza \& Varas. Corroborating the results obtained by (El Nesr et al., 2011) in studies conducted in different locations. However, the estimates of ETo using solar radiation data estimated with the non-calibrated models presented a greater dispersion of the values in comparison to the calibrated coefficients. The model of Weiss presented the best value of RMSE 0.73 , while the model of Donatelli \& Campbell, presented the worst performance among all models studied with RMSE 1.72.

However, it is not known by RMSE alone whether the model underestimates or overestimates the values. In this respect, the Mean Bias Error refers to the underestimation and overestimation of reference evapotranspiration. Table 5 shows that for the estimation of ETo, the values of solar 
radiation used when the coefficients are calibrated for the study place, they presented positive values, overestimating the ETo values. The solar radiation models without local calibration, when applied to the Penman - Monteith model to estimate ETo, showed a greater dispersion of the values. The Ann, DC, GD, and HS models overestimated ETo values, the WS model being the only one that underestimated the
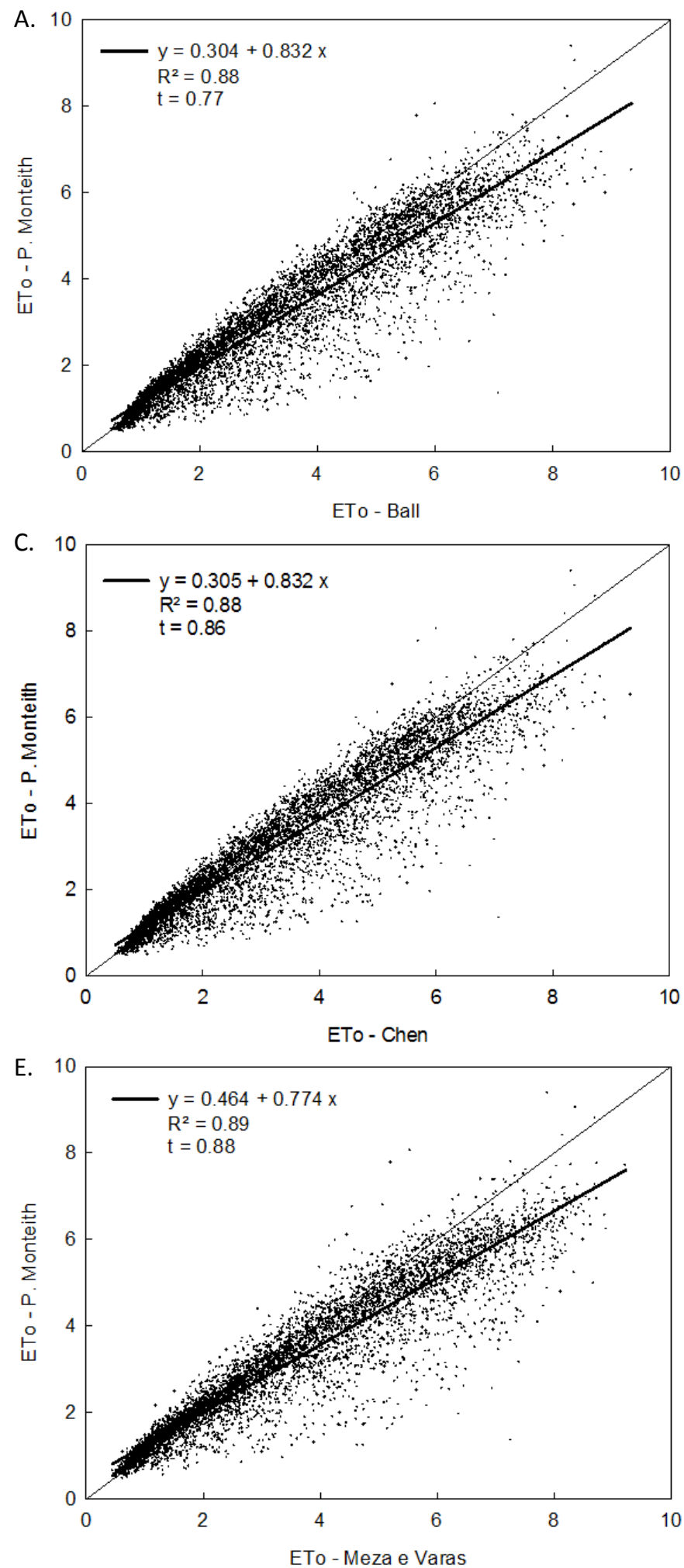

values. This indicates that when there is local calibration of solar radiation estimation models, the estimation of ETo by Penman - Monteith tends to present behavior similar to Sr.

The performance parameters of the models can be observed in (Table 6), where the classifications of the ETo estimates are presented through the use of the Sr estimation using models with calibrated and non-calibrated coefficients.
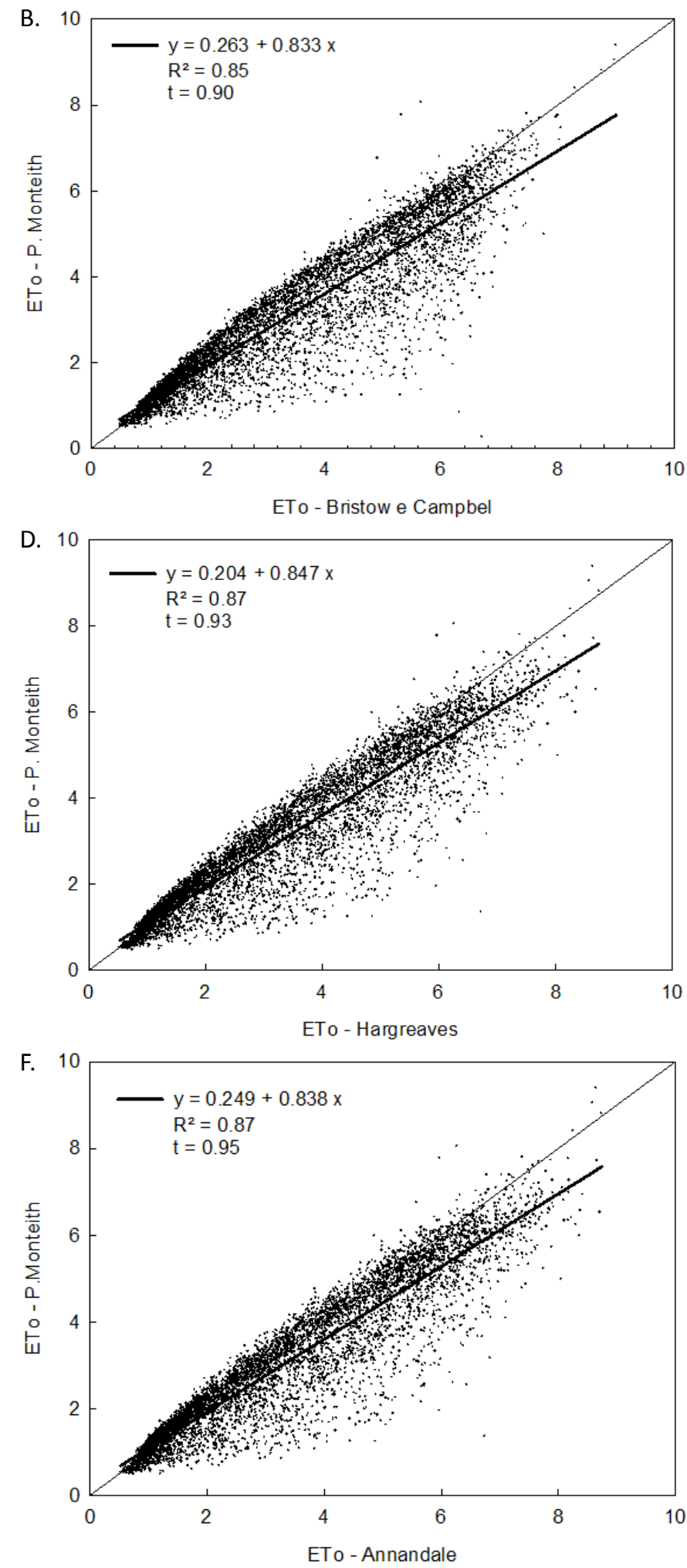

Continues on the next page 
Continued from Figure 2
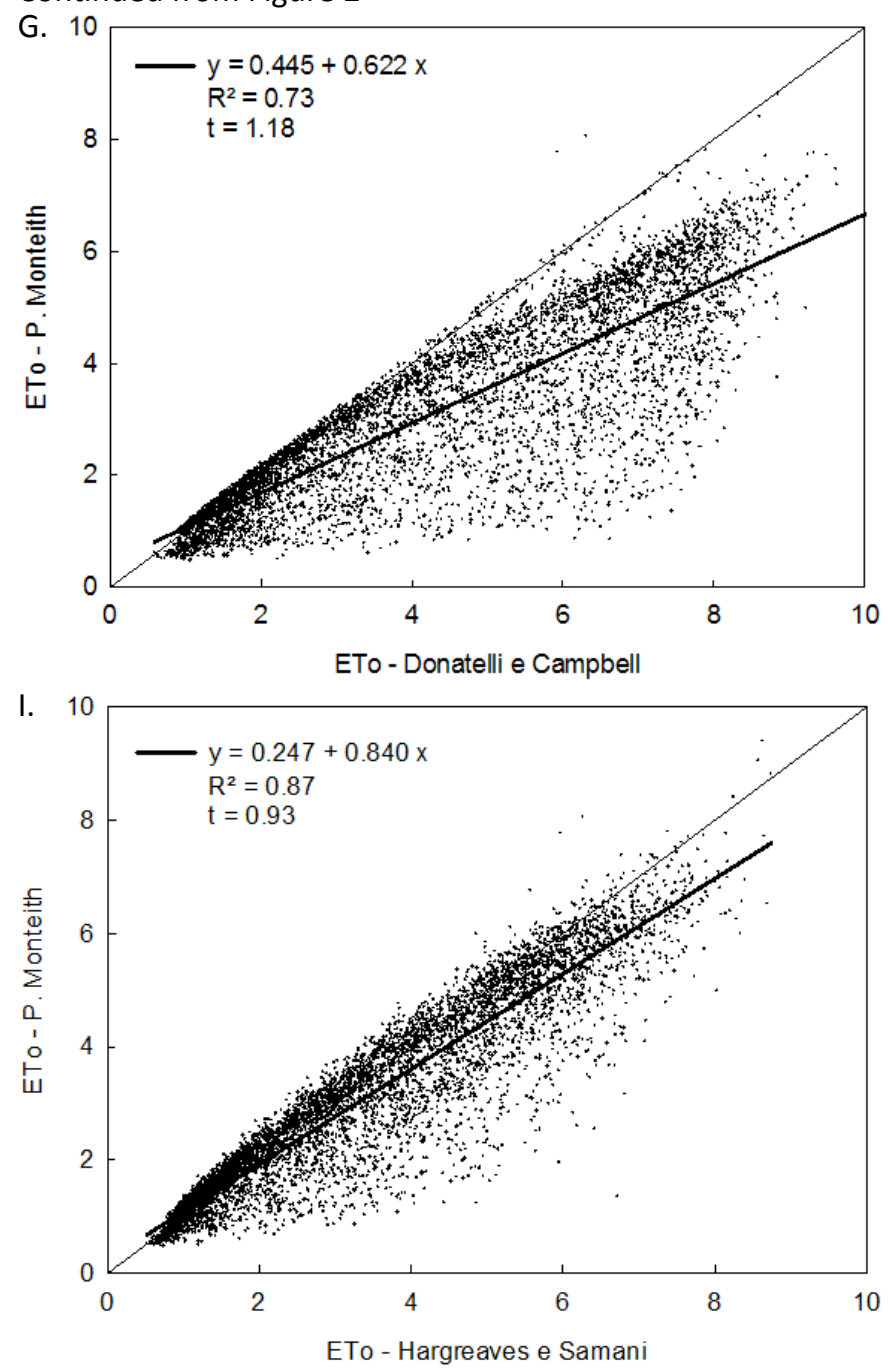
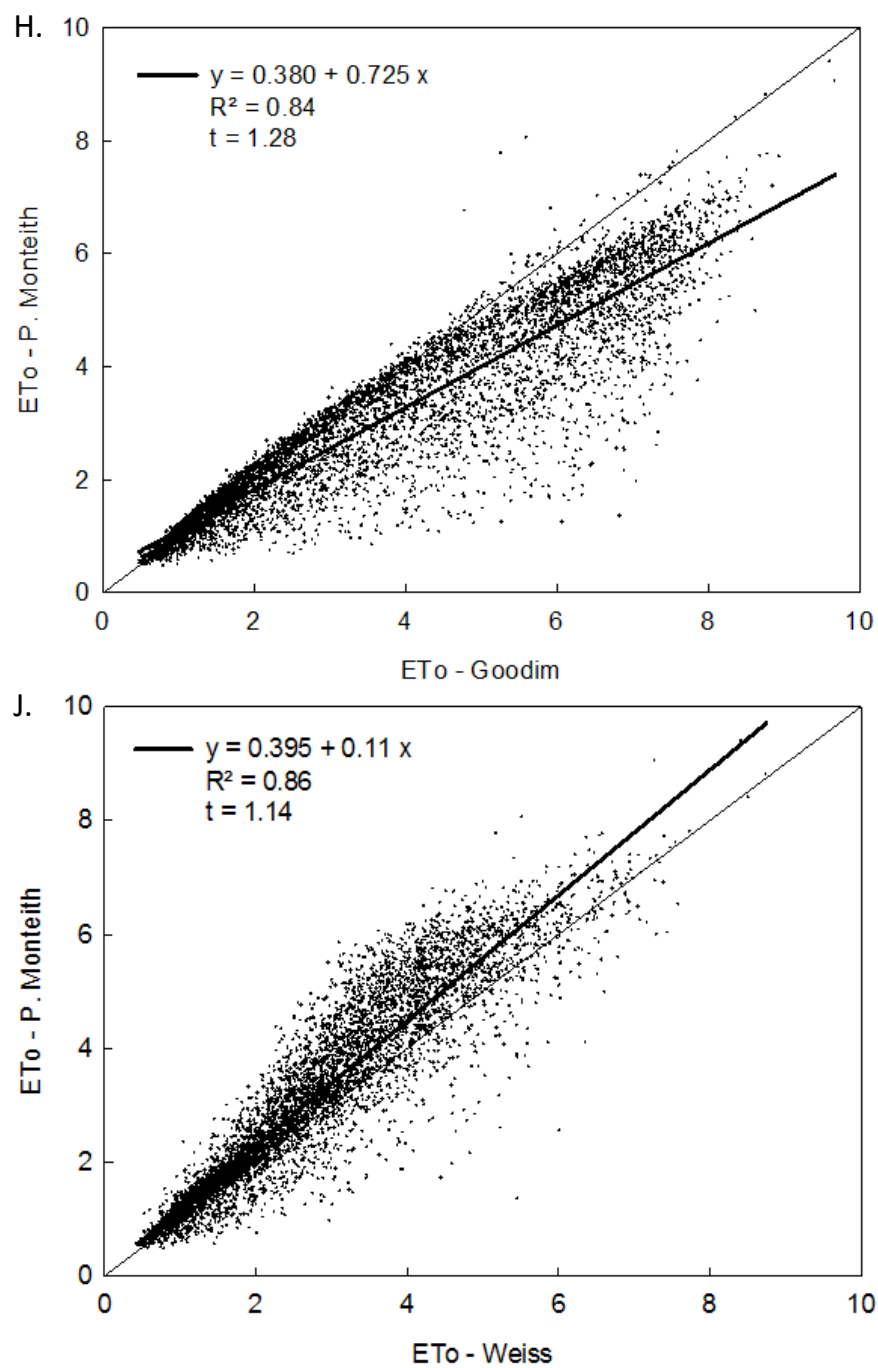

Figure 2. Values of the reference evapotranspiration estimated by Penman-Monteith as a function of the reference evapotranspiration values estimated by different models of solar radiation for Santa Maria - RS, Brazil.

Table 5. Root mean square error (RMSE), Mean Bias Error $(\mathrm{MBE})$, and Coefficient of Determination $\left(\mathrm{R}^{2}\right)$ to obtain the ETo estimate using solar radiation estimated by different models for Santa Maria - RS, Brazil.

\begin{tabular}{cccc}
\hline Models with calibration & RMSE & MBE & $\mathbf{R}^{\mathbf{2}}$ \\
Ball (BA) & 0.72 & 0.24 & 0.88 \\
Bristow \& Campbell (BC) & 0.79 & 0.31 & 0.85 \\
Chen (CH) & 0.72 & 0.27 & 0.88 \\
Hargreaves (Ha) & 0.74 & 0.30 & 0.87 \\
Meza \& Varas (MV) & 0.80 & 0.31 & 0.89 \\
\hline Models without calibration & & & \\
\hline Annandale (Ann) & 0.75 & 0.31 & 0.87 \\
Donatelli \& Campbell (DC) & 1.72 & 1.20 & 0.73 \\
Goodim (GD) & 1.11 & 0.66 & 0.84 \\
Hargreaves \& Samani (HS) & 0.74 & 0.30 & 0.87 \\
Weiss (WS) & 0.73 & -0.36 & 0.86 \\
\hline
\end{tabular}

It is observed that both the models with the calibration of their coefficients and the models without calibration showed little variability among themselves, with values from 0.96 to 1.0 for the index " $d$ ". These results corroborate those found by Conceição \& Marin (2005), for studies conducted in two
Table 6. Concordance Index (d), Correlation Coefficient ( $r$ ), and Performance Index (Id) of the ETo estimate using estimates of Sr by different models for Santa Maria - RS, Brazil.

\begin{tabular}{ccccc}
\hline Models with calibration & $\mathbf{d}$ & $\mathbf{r}$ & $\mathbf{I d}$ & Classification \\
\hline Ball (BA) & 1.0 & 0.94 & 0.93 & Excellent \\
Bristow \& Campbell (BC) & 0.98 & 0.92 & 0.91 & Excellent \\
Chen (CH) & 1.0 & 0.94 & 0.93 & Excellent \\
Hargreaves (Ha) & 1.0 & 0.93 & 0.92 & Excellent \\
Meza \& Varas (MV) & 0.98 & 0.94 & 0.93 & Excellent \\
\hline Models without calibration & & & & \\
\hline Annandale (Ann) & 1.0 & 0.93 & 0.92 & Excellent \\
Donatelli \& Campbell (DC) & 0.96 & 0.86 & 0.82 & Optimal \\
Goodim (GD) & 0.98 & 0.92 & 0.90 & Excellent \\
Hargreaves \& Samani (HS) & 1.0 & 0.93 & 0.92 & Excellent \\
\hline Weiss (WS) & 0.98 & 0.93 & 0.92 & Excellent \\
\hline
\end{tabular}

cities in the state of São Paulo, which verified values for " $d$ " of 0.88 and 0.86 , respectively, and (Lêdo et al., 2012) that found values of 0.61 to 0.64 for Barbalha - CE.

For the correlation coefficient " $r$ ", all the models presented a good ratio, above 0.92 for models with calibration and of 0.86 for models without calibration, being classified as excellent 
and optimal, showing a great linear statistical dependence among the variables.

For the performance index "Id", where values above 0.91 were obtained for models with calibration and 0.82 with Donatelli \& Campbell, this being the lowest result found for the models without calibration. For the other uncalibrated models, the mean values were 0.91, which, according to (Pimenta et al., 2018), classifies as excellent. Conceição \& Marin (2005) found performance classified as "Very Good" for the localities of Jales and Piracicaba-SP, with "Id" of 0.71 and 0.72 , respectively. Massignam (2007) found performance classified as "Moderate" in Itajaí, Pedras Grandes, and Florianópolis-SC, with "Id" of 0.46, 0.47 , and 0.48 respectively, and "Very Good" classification in the locality of Urussanga-SC, with an "Id" value of 0.76 . (Rodrigues et al., 2008) obtained "Moderate" performance for conditions of Limoeiro do Norte-CE, with "Id" of 0.45 .

\section{Conclusions}

Based on the results obtained, it can be concluded that there is no interference in the reference evapotranspiration estimate. Thus enabling the calculation of ETo, regardless of the calibration or not of the coefficients used in the study.

\section{Literature Cited}

Abraha, M.G.; Savage, M.J. Comparison of estimates of daily solar radiation from air temperature range for application in crop simulations. Agricultural and Forest Meteorology, v.148, n.3, p.401416, 2008. https://doi.org/10.1016/j.agrformet.2007.10.001.

Allen, R.G., Pereira, L.S., Raes, D., Smith, M. Crop evapotranspiration - Guidelines for computing crop water requirements. Rome: FAO, 1998. 300p. (FAO. Irrigation and Drainage Paper, 56).

Almorox, J. Estimating global solar radiation from common meteorological data in Aranjuez, Spain. Turkish Journal of Physics, v.35, n.1, p.53-64, 2011. http://journals.tubitak.gov.tr/ physics/issues/fiz-11-35-1/fiz-35-1-7-0912-20.pdf. 28 Jul. 2019.

Almorox, J.; Bocco, M.; Willington, E. Estimation of daily global solar radiation from measured temperatures at Cañada de Luque, Córdoba, Argentina. Renewable Energy, v. 60, p. 382-387, 2013. https://doi.org/10.1016/j.renene.2013.05.033.

Alvares, C.A.; Stape, J.L.; Sentelhas, P.C.; Gonçalves, J.L. de M.; Sparovek, G. Köppen's climate classification map for Brazil. Meteorologische Zeitschrift, v.22, n.6, p.711-728, 2013. https:// doi.org/10.1127/0941-2948/2013/0507.

Annandale, J.G.; Jovanic, N. Z.; Benade, N.; Allen, R. G. Software for missing data error analysis of Penman-Monteith reference evapotranspiration. Irrigation Science, v.21, n.2, p.57 - 67, 2002. https://doi.org/10.1007/s002710100047.

Ball, R.A.; Purcell, L.C.; Carey, S.K. Evaluation of solar radiation prediction models in North America. Agronomy Journal, v.96, n.5, p.391-397, 2004. https://doi.org/10.2134/agronj2004.1498.

Bandyopadhyay, A.; Bhadra, A.; Raghuwanshi, N.S.; Singh, R. Estimation of monthly solar radiation from measured air temperature extremes. Agricultural and forest meteorology, v.148, n.11, p.17071718, 2008. https://doi.org/10.1016/j.agrformet.2008.06.002.
Benghanem, M.; Mellit, A. A simplified calibrated model for estimating daily global solar radiation in Madinah, Saudi Arabia. Theoretical and applied climatology, v.115, n.1-2, p.197-205, 2014. https://doi.org/10.1007/s00704-013-0884-2.

Besharat, F.; Dehghan, A.A; Faghih, A.R. Empirical models for estimating global solar radiation: a review and case study. Renewable and Sustainable Energy Reviews, v.21, p.798-821, 2013. https://doi.org/10.1016/j.rser.2012.12.043.

Bristow, K.L.; Campbell, G.S. On the relationship between incoming solar radiation and daily maximum and minimum temperature. Agricultural and Forest Meteorology, Philadelphia, v.31, n.2, p.159 - 166, 1984. https://doi.org/10.1016/0168-1923(84)90017-0.

Camargo, A.P.; Sentelhas, P.C. Avaliação de desempenho de diferentes métodos de estimativa de evapotranspiração em potencial no estado de São Paulo, Brasil. Revista Brasileira de Agrometeorologia, v.5, n.1, p.89-97, 1997. https://www. researchgate.net/publication/284194031. 02 Ago. 2019.

Carvalho, D.F.D.; Silva, D.G.D.; Souza, A.P.D.; Gomes, D.P.; Rocha, H.S.D. Coeficientes da equação de Angström-Prescott e sua influência na evapotranspiração de referência em Seropédica, Estado do Rio de Janeiro, Brasil. Revista Brasileira de Engenharia Agrícola e Ambiental, v.15, n.8, p.838-844, 2011. https://doi. org/10.1590/S1415-43662011000800011.

Chen, R.S.; Ersi, K.; Yang, J.P.; Lu, S.H.; Zhao, W.Z. Validation of five global radiation models with measured daily data in China. Energy Conversion and Management, v.45, n.11-12, p.17591769, 2004. https://doi.org/10.1016/j.enconman.2003.09.019.

Conceição, M.A.F. Evapotranspiração de referência baseada na radiação solar global estimada pelo método de Bristow e Campbell. Engenharia Agrícola, v.30, n.4, p.619-626, 2010. https://doi.org/10.1590/S0100-69162010000400006.

Conceição, M.A.F.; Marin, F.R. Estimativa da radiação solar incidente com base na amplitude térmica diária. In: Congresso Brasileiro de Agrometeorologia, 14., 2005, Campinas. Anais ... Campinas: Sociedade Brasileira de Agrometeorologia, 2005. CD-Rom.

Donatelli, M.; Campbell, G.S. A simple model to estimate global solar radiation. In: Congress of the European Society for Agronomy, 5., 1998, Nitra. Proceedings... Nitra: The Slovak Agricultural University, 1998. p.133-134.

El Nesr, M.N.; Alazba, A.A.; Amin, M. T. Modified Hargreaves' method as na alternative to the Penman-Monteith method in the Kingdom of Saudi Arabia. Australian Journal of Basic and Applied Sciences, v.5, n.6, p.1058-1069, 2011. http://www.ajbasweb. com/old/ajbas/2011/june-2011/1058-1069.pdf. 25 Ago. 2019.

Fan, J.; Chen, B.; Wu, L.; Zhang, F.; Lu, X.; Xiang, Y. Evaluation and development of temperature-based empirical models for estimating daily global solar radiation in humid regions. Energy, v.144, p. 903-914, 2018a. https://doi.org/10.1016/j. energy.2017.12.091.

Fan, J.; Wang, X.; Wu, L.; Zhou, H.; Zhang, F.; Yu, X.; Xiang, Y. Comparison of support vector machine and extreme gradient boosting for predicting daily global solar radiation using temperature and precipitation in humid subtropical climates: a case study in China. Energy Conversion and Management, v.164, p. 102-111, $2018 \mathrm{~b}$. https://doi.org/10.1016/j.enconman.2018.02.087. 
Faria, R. T. de; Caramori, P. H.; Chibana, E. Y.; Brito, L. R. de S .; Nakamura, A. K .; Ferreira, A. R. Climate - computer program for organizing and analyzing meteorological data. Londrina: IAPAR, 2002. 29p. (IAPAR. Technical Bulletin, 66).

Goodin, D.G.; Hutchinson, J.M.S.; Vanderlip, R.L.; Knapp, M.C. Estimating solar irradiance for crop modelling using daily air temperature data. Agronomy Journal, Wooster, v.91, n.5, p.845851, 1999. https://doi.org/10.2134/agronj1999.915845x.

Hargreaves, G.H. Responding to tropical climates. In: Slater, L.E. (Ed.). The 1980-81 Food and Climate Review. The Food and Climate Forum. Boulder: Aspen Institute for Humanistic Studies, 1981. p.29-32.

Hargreaves, G.H.; Samani, Z.A. Estimating potential evapotranspiration. Journal of the irrigation and Drainage Division, v.108, n.3, p.225-230, 1982.

Hassan, G.E.; Youssef, M.E.; Mohamed, Z.E.; Ali, M.A.; Hanafy, A.A. New temperature-based models for predicting global solar radiation Applied energy, v.179, p.437-450, 2016. https://doi. org/10.1016/j.apenergy.2016.07.006.

Jahani, B.; Dinpashoh, Y.; Nafchi,; A.R. Evaluation and development of empirical models for estimating daily solar radiation. Renewable and Sustainable Energy Reviews, v. 73, p. 878-891, 2017. https:// doi.org/10.1016/j.rser.2017.01.124.

Jamil, B.; Akhtar, N. Comparison of empirical models to estimate monthly mean diffuse solar radiation from measured data: case study for humid-subtropical climatic region of India. Renewable and Sustainable Energy Reviews, v.77, p.1326-1342, 2017. https://doi.org/10.1016/j.rser.2017.02.057.

Lêdo, E.R.F.; Silva, M.G.; Nogueira, D.H.; Arraes, F.D.D. Avaliação de modelo de estimativa da radiação solar global (Rs) com base na amplitude térmica. Conexões -Ciência e Tecnologia, v.6 n.1, p.15-26, 2012. http://conexoes.ifce.edu.br/index.php/conexoes/ article/view/478. 02 Ago. 2019.

Lemos Filho, L.C.; Carvalho, L.G.; Evangelista, A.W.; Alves Júnior, J. Análise espacial da influência de elementos meteorológicos na evapotranspiração de referência em Minas Gerais. Revista Brasileira de Engenharia Agrícola e Ambiental, v.14, n.12, p.12941303, 2010. https://doi.org/10.1590/S1415-43662010001200007.

Liu, X.; Mei, X.; Li, Y.; Wang, Q.; Zhang, Y.; Porter, J.R. Variation in reference crop evapotranspiration caused by the Angström - Prescott coefficient: locally calibrated versus the FAO recommended. Agricultural Water Management, v.96, n.7, p.11371145, 2009. https://doi.org/10.1016/j.agwat.2009.03.005.

Macêdo, K.G.; Oliveira, J.B.; Arraes, F.D.D .; Torres, W.L.V .; Lima Junior, J.C. Estimativa da radiação solar global com dados de temperatura do ar em seis cidades do estado do Ceará. Engenharia na Agricultura, v.24, n.1, p. 68 - 75, 2016. https://doi. org/10.13083/reveng.v24i1.612.

Massignam, A. M. Estimativa da radiação solar em função da amplitude térmica. In: Congresso Brasileiro de Agrometeorologia, 15., 2007, Aracaju. Anais ... Aracaju: Sociedade Brasileira de Agrometeorologia, 2007. CD Rom.

Meza, F.; Varas, E. Estimation of mean montlhy solar global radiation as a function of temperature. Agricultural and Forest Meteorology, v.100, n. 2-3, p.231- 241, 2000. https://doi.org/10.1016/S01681923(99)00090-8.
Minuzzi, R.B.; Ribeiro, A.J.; da Silva, D.O.; Kuneski, A.C. Evapotranspiração de referência diária estimada pela PenmanMonteith FAO com dados de temperatura do ar para Santa Catarina. Irrigação, v.19, n.4, p.548, 2018. https://doi. org/10.15809/irriga.2014v19n4p548.

Mohammadi, K.; Shamshirband, S.; Kamsin, A.; Lai, P.C.; Mansor, Z. Identifying the most significant input parameters for predicting global solar radiation using an ANFIS selection procedure. Renewable and Sustainable Energy Reviews, v.63, p. 423-434, 2016. https://doi.org/10.1016/j.rser.2016.05.065.

Mostafa, Z.A.; Maghrab, A.H.; Shehri, S.M. Sunshine-based global radiation models: a review and case study. Energy Conversion and Management, v.84, p.209-216, 2014. https://doi.org/10.1016/j. enconman.2014.04.021.

Pereira, L.S.; Allen, R.G.; Smith, M.; Raes, D. Crop evapotranspiration estimation with FAO56: Past and future. Agricultural Water Management, v.147, p.4-20, 2015. https://doi.org/10.1016/j. agwat.2014.07.031.

Pimenta, B.D.; Robaina, A.D.; Peiter, M.X., Mezzomo, W.; Kirchner, J. H.; Ben, L.H.B. Desempenho de aproximações explícitas do coeficiente de perda de carga para condutas pressurizadas. Revista Brasileira de Engenharia Agrícola e Ambiental, v.22, n.5, p.301-307, 2018. https://doi.org/10.1590/1807-1929/agriambi. v22n5p301-307.

Quej, V.H.; Almorox, J.; Ibrakhimov, M.; Saito, L. Empirical models for estimating daily global solar radiation in Yucatán Peninsula, Mexico. Energy Conversion and Management, v.110, p.448-456, 2016. https://doi.org/10.1016/j.enconman.2015.12.050.

Rodrigues, D.N.B. et al. Radiação solar global estimada por amplitude térmica diária. In: Congresso Nacional de Irrigação e Drenagem, 18., 2008, Belo Horizonte. Anais ... Belo Horizonte: ABID, 2008. CD-Rom.

Systat. Systat for Windows version 5.01. Chicago: Systat Software Inc., 2002.

Tabari, H.; Hosseinzadehtalaei, P.; Willems, P.; Martinez, C. Validation and calibration of solar radiation equations for estimating daily reference evapotranspiration at cool semi-arid and arid locations. Hydrological Sciences Journal, v.61, n.3, p.610-619, 2016. https:// doi.org/10.1080/02626667.2014.947293.

Tagliaferre, C.; Paula, A.; Rocha, F.A.; Campos, W.V.; Guimarâes, D.U.G. Influência dos elementos meteorológicos na evapotranspiração de referência estimada utilizando-se o Irrigâmetro no município de Guanambi-BA. Revista Engenharia na Agricultura, v.23, n.3, p.251-260, 2015. https://doi.org/10.13083/1414-3984/reveng. v23n3p251-260.

Togrull, T.; Togrul, H. Global solar radiation over Turkey: comparison of predicted and measured data. Renewable Energy, v.25, n.1, p.55-67, 2002. https://doi.org/10.1016/S0960-1481(00)00197-X.

Weiss, A.; Hays, C.J.; Hu, Q.; Easterling, W.E. Incorporating bias error in calculating solar irradiance: implications for crop yield simulations. Agronomy Journal, v.93, n.6, p.1321-1326, 2001. https://doi.org/10.2134/agronj2001.1321.

Willmott, C.J. On the validation of models. Physical Geography, v.2, n.2, p.184-194, 1981. https://doi.org/10.1080/02723646.1981.1 0642213. 